\title{
Implementing Interreligious Dialogue
}

\author{
A Solution for International Challenges? (Universal Peace \\ Federation / 2005-2009)
}

\section{Introduction}

In the landscape of contemporary interreligious dialogue, the Universal Peace Federation (UPF) takes up a unique place. Founded in 2005, it is one of the newest organizations in this field. Moreover, UPF is run, unlike other international interreligious dialogue (or interfaith) organizations, by one religion: The Unification Church, a new religious movement started in South Korea by Rev. Sun Myung Moon in the mid-20th-century. Considering the fact that most interfaith activities have thus far been performed by "mainstream" religious entities inside Islam and Christianity, the two above facts allow us to fathom how UPF is different from other interreligious dialogue organizations.

Although UPF carries distinctive characteristics of its own, it also has deep continuity with the history of interfaith dialogue made clear when examining its foundational works on interfaith enterprise as early as the 1970s. This is due to the idea of interreligious dialogue being embedded in the doctrine of the Unification Church. At the same time, its initiatives and projects are also closely tied to UN engagement. As a non-governmental organization (NGO) with religious voices among its representatives, UPF has actively participated in the Economic and Social Council (ECOSOC) of the United Nations.

From these above basic facts, we can clearly see that UPF has complex features that need examining. Therefore, this chapter primarily aims to analyze the background and foundation of UPF. In the course of the investigation, this study finds that the inauguration of UPF reflects the situation after 9/11. That is to say, the radical change in international politics and religious field since 2001 propelled the foundation of UPF. This new organization did not start out of nowhere; the historical context of interfaith dialogue and the previous activities of the Unification Church buttressed its foundation.

Hence, this chapter posits that there are the two major factors that led to the foundation of UPF: (1) the historical changes that influenced and formed the milieu for this new interreligious initiatives; and (2) the existing agents who were already devoted to interreligious dialogue and had the know-how regarding in- 
terfaith activities. UPF is a new organization that must be understood as part of a continuum, having been preceded by the Interreligious and International Federation for World Peace (IIFWP), which is a specialized organization with highly experienced staffs in the realm of international NGOs. This chapter, therefore, focuses on the transition from IIFWP to UPF in relation to the above two factors.

This study is composed of three parts. The first section is a preliminary account on the background of UPF and an explanation about its methodology. This includes a brief history of UPF, clarifying the place of UPF within the overall history of interfaith dialogue. Also, it describes the socio-political surroundings. Then, the methodology and materials that are used in the report are introduced; this report predominantly relies on empirical and historical research based on written documents; the interviews with the members of the organization were also used to structure this research. This methodology is necessary to probe the hypothesis on the interaction of historical settings and the existing agents in the organization. In the second section, which is the main part of this chapter, the foundation phase of UPF is analyzed in detail. Several important episodes found in the archival documents and interviews with people in UPF formed the basis of this chapter. The final section summarizes previous parts and also compares the initial hypothesis and the research results. They will illuminate the implications and the context within which UPF was founded and its place within the contemporary IRD field.

\section{Understanding the Universal Peace Federation: Background and Methodology}

\subsection{The Unification Church and the Universal Peace Federation}

Before getting into the details of UPF, it is essential to understand that this organization is one of the enterprises that the Unification Church has been running for a long time. Thus, it is necessary to first take a brief look into the history of the Unification Church and determine the status that UPF takes on inside this new religious movement. The Unification Church was founded in 1954, in Seoul, South Korea, under the name of "Holy Spirit Association for the Unification of World Christianity" by Rev. Sun Myung Moon. According to Frederick Sonntag, a philosopher and writer who conducted an expansive interview with 
Rev. Moon in the 1970s, the founder of the Unification Church received a revelation from God on an Easter morning 1938 and maintained his vision since then. ${ }^{1}$

The founder's vision has always been one of the most important motivations of the Unification Church. Rev. Sun Myung Moon was born in 1920 in a rural town of what is now North Korea. His family had a Presbyterian background. ${ }^{2}$ His life became traumatic during the Japanese occupation and the subsequent Korean War. He was educated in Korea and then in Japan. Later he returned to Korea to spread his religious vision. However, in 1948, he was imprisoned in North Korea for not conforming to communist ideology under the Soviet occupation. From that experience, he expressed a clear anti-communist stand, which always persisted in his speeches and arguments subsequently. He was liberated by the United Nations (UN) forces and moved to South Korea in 1950.

In the 1950s, Rev. Sun Myung Moon formalized his religious movement into a church. Along with the official establishment of the Unification Church in 1954, he gradually developed his interpretation of the Bible and started to publish his own independent scripture from 1952 onwards. The completed version of 'The Divine Principle', the central scripture of the Unification Church, appeared in 1966 (the English version appeared in 1973). ${ }^{3}$ This scripture was largely based on the interpretation of the story in Genesis and the role of the founder as a Messiah. In his interpretation, the story of Adam and Eve represents the failure to accomplish a harmonious family. Also, in his opinion, Jesus failed to complete the mission of God, since he was murdered before establishing a God-blessed family. Therefore, the founder has carried this mission to complete unfinished work of the previous prophet, namely Jesus, from which the famous mass marriage ritual of the Unification Church is derived.

After increasing its power and size in Korea throughout the 1960s, the Unification Church actively started to spread its ideals around the world. ${ }^{4}$ Pointedly, Rev. Moon moved to the US in the early 1970's and embarked on this mission. The Unification Church's lucrative business, mode of mission and Christian-de-

1 Information on the foundation of Unification Church is from Frederick Sontag, Sun Myung Moon and Unification Church (Nashville: Abingdon, 1977), 78.

2 Sontag, Sun Myung Moon, 77-80.

3 George D. Chryssides, The Advent of Sun Myung Moon (New York: St. Martin's Press, 1991), 23.

4 The early missionary activities of the Unification Church are well accounted here: David G. Bromley and Anson D. Shupe, Jr, "Moonies" in America (Thousand Oaks: Sage Publication, 1979), 57-82. Also, detailed description on the movement's early activity and organization can be found in here: Rodney Stark and John Lofland, "Becoming a World-Saver: A Theory of Conversion to a Deviant Perspective," American Sociological Review 30/6 (1965): 862-875. The research subjects are mentioned under pseudonym. 
rived doctrine have aroused much debate, controversy, as well as questions of heresy in the United States (US). For instance, Rev. Moon's alleged involvement in politics in the 1970s and his imprisonment due to tax evasion in the US (1984) shows the fact that he and the movement were 'issue-makers' in the USA during the 1970s-80s. ${ }^{5}$ In this period, there was a large number of converts worldwide and the size of the Unification Church reached its peak. ${ }^{6}$

After those heydays in the US, the Unification Church has somewhat diminished in size, but still remains as one of the most prominent new religious movements in the world. In 1997, the Unification Church internationally re-launched under the name "The Family Federation for World Peace and Unification" (FFWPU). This change gave the movement less of a religious overtone since it does not explicitly proclaim to be a religious organization. ${ }^{7}$ It appeared that the movement tried to embrace a more comprehensive scale of groups and individuals beyond religious institutions. Although hundreds of local branches still definitely see themselves as churches and "congregations" and the movement is still largely motivated by its religious agenda, the name change into FFWPU reflects the more recent vision of the movement.

With this brief history of the Unification Church in mind, this chapter now moves to examine what place UPF occupies in the overall picture of the movement. To understand the characteristics of UPF, it is necessary to understand that the whole movement consists of various organizations and businesses that can be compared to a conglomerate company: according to the entry on the Unification Church in the Encyclopedia of Global Religion, the number of business or organization linked to the Unification Church amounts to 1,000 worldwide. They include "Ambassadors for Peace: Bridgeport University; CARP; Il Hwa; International Cultural Foundation; Inter-Religious Federation for World Peace; Professors World Peace Academy; Tong Il; and Women's Federation for World Peace, and so on." ${ }^{8}$ Hence, UPF can be considered one of the organizations run by the Unification Church today. ${ }^{9}$

5 Bromly et al, "Moonies" in America, 149-167.

6 Dawn Hutchinson, Antiquity and Social Reform (Newcastle: Cambridge Scholars Publishing, 2010), 26-42; Sun Myung Moon and Unification Church, 44-69.

7 "Many members of the FFWPU accept and follow Reverend Moon's particular religious teaching, the Divine Principle, and are known as Unificationists. The FFWPU was founded in 1997 by Reverend and Mrs. Moon in order to expand the mission of the Unification Church to create an alliance of people who generally share their vision of building God-centered families as the basis for healthy communities, stable societies and a peaceful world.” https://ihq.ffwpu.org/who weare/ (accessed: 24.5.2020).

8 Eileen Barker, "Unification Church," in Encyclopedia of Global Religion, ed. Mark Juergensmeyer and Wade Clark Roof (Thousand Oaks Sage Publications, 2012): 1319-1321. 
What distinguishes UPF from other organizations of the Unification Church is the fact that interreligious dialogue and "unification" among the religions have been major concerns of the movement based on its doctrine. According to Marcus Braybrooke, a noted Anglican interfaith scholar, the Unification Church has advanced its interfaith dialogue project to realize its ideal "toward

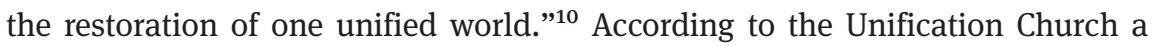
unified world will be made possible by creating a unified cultural sphere. Thus, the role of religions and their unification is essential for the agenda. Braybrooke quotes Rev. Moon's words on this vision:

... as representatives of the world's religions, you are called to bring your churches, mosques, synagogues, ashrams, and temples into a cooperative unity for the sake of world peace and human freedom, centered on God. ${ }^{11}$

Braybrooke traces the interfaith activities of the Unification Church back to as early as 1977. Starting from the Global Congress of the World's Religions held in San Francisco (1977), several congresses and councils were founded and funded by the Unification Church. Those include the Global Congress of World Religions, and the Council for the World's Religions (1980). In this formative period, the New Ecumenical Research Association (the New ERA) conferences with other Christian academics and the organization of the International Religious Foundation (IRF) were precursors of later Unification Church interreligious dialogue activities. The Unification Church's interfaith work continued with the Assembly of World's Religions, which started in 1985, with a large conference and event with religious leaders from other religions. Braybrooke describes the group discussions in the Assemblies as one of the most fruitful dialogue experiences. ${ }^{12}$

9 There has been a few researches on the Unification Church in the latter half of the 20th-century Anglophone world. For the general list of research, see Antiquity and Social Reform, 23-26. Here, Hutchinson lists existing scholarship on the Unification church. However, there have been many works that are largely derogatory to the movement, and they usually name the movement as "moonism." The exception is "Moonies" in America. Here, Bromley and Shupe analyze the movement from a sociological standpoint. I think that Sun Myung Moon and Unification Church provides a relatively objective and accurate picture on the movement in the late 70's. More elaborated and multi-dimensional work on the Unification Church from an academic perspective is The Advent of Sun Myung Moon, which studies the Korean traditional context and its interminglement with Christianity as the background of Unificationism.

10 Marcus Braybrooke, Pilgrimage of Hope (Philadelphia: Trinity Press International, 1991), 270. 11 Braybrooke, Pilgrimage of Hope, 270. He mentions that this is from The Fourth International Conference on God, which was held in Seoul, August 11, 1984.

12 Braybrooke, Pilgrimage of Hope, 276. Adding to this, we can refer to the remarks of Dr. Walsh in an interview that I conducted in July 10, 2014: "There were also an interest in Unification 
As we can see, there were a lot of interfaith organizations, seminars and conferences promoted by the Unification Church. This fact proves that interreligious dialogue was not a one-time subject for the movement. Intertwined with its doctrine and ideal for a unified culture and the world, the Unification Church developed its agenda of interfaith dialogue. It seems that its activities from the 1970s to 1980s focused on academic interchanges, opening up the doors for interfaith conversation and promoting its agenda and initiatives to various religious entities. In 1991, the foundation of the Inter-Religious Federation for World Peace (IRFWP) by Rev. Moon was an organizational shift to realize the existing agenda with a more systematic effort.

However, from the late 1990s, Unification Church started to promote another project: a vision of a religious council in the United Nations. Building on its previous work for interreligious dialogue, the Unification Church started to exert its efforts in creating a new and more effective sphere for interfaith dialogue and engagement. The foundation of (Interreligious and International Federation for World Peace, 1999 (IIFWP) and its 2000 Assembly, "Renewing the United Nations and Building a Culture of Peace" clearly show these new objectives. Let us observe a part of the proceedings of the conference. First, the keynote address of Rev. Sun Myung Moon is as follows:

... one of the reasons I founded the Interreligious and International Federation of World Peace was to help create an interreligious assembly to serve as a senate or council within the United Nations. To implement that plan, I propose that each nation, in addition to its

Church, this new religious movement. And that involvement gave birth to the first interfaith organization, that Rev. Moon established in the West called The New Ecumenical Research Association, for short, NEW ERA. (...) And one of the flagship project of the New ERA that began on the 1980's something called, it was a conference series, on "God: the contemporary discussion." So for about ten years, every year there was a God conference. It was interfaith. And I would say new ERA tended to be scholarly. Little more than clergy centered. There's a difference between academicians who may be Jewish or Buddhist or they teach Buddhism, they love Buddhism, but they are academics. like even Leonard Swidler type, he's roman Catholic, and still Roman Catholic, when he talks in a conference, he doesn't say this is what the Pope believes, this is what the catholic believes, he's a broader, because his mind is filled with, and this is what characterizes, many, this Western academics, in some ways academic community globally tends to observe religion a little more objectively, and can differentiate between their own faith and their professional responsibilities. Then so it started to create, that's why an idea, that's why I used the family of a tree almost like a genealogy of tree or something. Kind of UTS, New ERA, The God conference series started then out of the God conference." 
current ambassador, send a religious ambassador to the United Nations to serve as a member of the religious assembly, or U.N. senate. ${ }^{13}$

Here, Moon's vision is clearly articulated. He insists that a distinctive and independent council be implemented inside the UN system. To realize this goal, he called for the participation of other religious entities as well. This goal was highly ambitious since it asked for the UN, a nation-state based international organization, to embrace a new set of influence within its structure: religious groups. In this context, IIFWP was founded. The launching of IIFWP is one of the pivotal background events of UPF, upon which I shall expound more in section three further below.

\subsection{Remarks on Methodology}

\subsubsection{Material Used for the Analysis}

The methodology of this analysis largely relies on the documental resources found at the UPF's office: e.g. official proceedings of various conferences, documents on the logistics of each of the events UPF held, seminar materials, etc. Additionally, this analysis includes interviews with the core members of UPF who worked for the organization and interreligious dialogue for more than 15 years. These two kinds of sources-office documents and interviews-help to examine the core episodes behind the foundation of UPF.

To understand the characteristic of the materials used in this research, it is necessary to understand the organization's activity. So far, the organization has not been the subject of any academic study or research, probably due to its relatively new foundation. But it may also be because it falls outside the mainstream Western religious entities. The organization can be said to be the first of its kind in the history of interreligious activity. Hence the observations about this organization found in this chapter are primarily based on the UPF website and my own experience interacting with members of this organization. ${ }^{14}$

13 IIFWP, Renewing the United Nations and Building a Culture of Peace: A Report from the Interreligious and International Federation for World Peace Assembly 2000 (New York: IIFWP, 2000), 58.

14 The official Web site of Universal Peace Foundation, ed. Universal Peace Foundation: http:// www.upf.org/ (accessed: 24.5.2020). However, the considerable volume of the materials is still not digitized, hidden in a staff's hard drive, or lost with a broken Web link. However, in the course of my research, I requested certain materials and one staff person found them in his 
The UPF headquarters is located in an office complex in Tarrytown, New York. As mentioned earlier, the office is the workplace of an NGO, not a library or an archive. ${ }^{15}$ There are about 9-10 regular staff-members in the organization, working for specific events and convocations of the organization. ${ }^{16}$ They manage the planning and implementation of the events over which the organization presides. For example, UPF holds a number of international conferences, including the largest World Summit in Seoul twice a year, participates in ECOSOC meetings, leads World Interfaith Harmony Week, organizes Religious Youth Service, etc. The organization's scope of activity is fairly expansive, and it requires much effort to thoroughly understand them.

\subsubsection{Potentials and Limits}

Since UPF is a recently founded organization and still active, there is a constantly growing body of sources that can be utilized for the analysis of the organization. Though they are well maintained in the office and in the warehouse of UPF, they are not well organized or classified for any archival purposes. Admittedly, UPF owns a powerful online archive that contains most of its important conference materials (http://archive.upf.org/). However, this archive has been recently constructed and does not include exhaustive sources concerning the period between 2000 and 2005.

As an international NGO, UPF owns an office that handles the practical and specific tasks of the organization. This means that they do not particularly aim at archiving and sorting materials for research. The materials were reasonably organized, but mostly for practical usages, and the online archive did not allow for access to the period of the research's interest. Therefore, there are certain limitations on the available sources on the foundation of UPF. The researcher had to resort to searching for boxes of documents and then sort them from the start. The

hard drive. I also reported several dead links on the Web archive to Mrs. Pople. Moreover, as dates go back to around 2005, the amount of materials uploaded on the Web archive decreases. For example, between 2000 and 2005, the period during which the important foundation events of UPF occurred, only a small number of documents are to be found on the Web, compared to the later dates. I did my fieldwork in the office of UPF from July 6-23, 2014.

15 When I arrived at the office, the staff members were busy preparing the World Summit 2014 in Seoul. They were inviting dozens of VIPs from all around the world and making appointments for various transportations.

16 The number of staff in other branches of UPF needs to be counted separately. For example, in the 2014 World Summit held in Seoul, I encountered dozens of UPF staffs working for the logistics and practical aspects, from all around the world. 
following are most of the documents that deal with logistics: the reservation of venue of the event, booking flights for the guests, the design drafts for the catalogue, the list of participants, etc.

To navigate among these sources, the interviews with the people in the organization were helpful. Since UPF is a relatively new organization, most of its members who witnessed the foundation of UPF, or the transition of IIFWP to UPF, are still working in the office. They know which files contained the information needed for this study and even, in some cases, became primary sources when interviewed by me. By closely communicating with them, this paper has greatly benefited from their navigation. ${ }^{17}$

\subsubsection{Process of the Analysis}

This research is primarily based on the aforementioned documents and interviews. The two kinds of materials serve each other in a complementary manner. As qualitative research methodology was employed in dealing with the documents, the context and environment that produced the document needed to be considered..$^{18}$ In fact, the single documents only tell us the basic and superficial information on the events. Analyzing the characteristic of the documents gave further insight.

To be specific, the materials from the archive and the office of UPF can be categorized as public/private or firsthand/secondhand document. ${ }^{19}$ Moreover, the implied readers of the documents also need to be considered. These aspects create a contextual environment that can be utilized to recount the story behind the materials. ${ }^{20}$ To analyze an interreligious movement, the motivation and symbolic system of the actors in the organization and the event needs to be considered with great attention since the interreligious activity itself can also be seen as

17 My core interviewees were: Dr. Thomas Walsh, Mr. Taj Hamad, Ms. Genie Kagawa, and Dr. Frank LeGroterria.

18 Amanda Coffey, “Analyzing Documents," in The SAGE Handbook of Qualitative Data Analysis, ed. Uwe Flock (London: SAGE Publications, 2014), 368.

19 Coffey “Analyzing Documents,” 377.

20 That is to say, I try to figure out what Coffey said as "representative of the practical accomplishments involved in their production" in the below quotation: "All documentary accounts are just that - a constructed account rather than necessarily an 'accurate' portrayal of complex social reality. [....] It is therefore important that we approach documents as texts and as representative of the practical accomplishments involved in their production." Coffey, "Analyzing Documents," 377. 
a religious phenomenon. Hence, considering contextual factors is essential to illuminate the religious dimension and accurately account for them.

Handling interview materials calls for another methodological delineation. Dealing with the interviews regularly requires a whole other set of methodological considerations. ${ }^{21}$ However, this analysis only utilizes interview materials as an orientation for documental research. This essay mainly consists of the analysis of the archival sources, rather than regular analysis of the interviews. Thus, the interviews illuminate the exact context of the documents, helping this analysis to avoid misinterpretation. In-depth analysis of interview scripts is not conducted here, but they are used as an index of this essay for investigating core episodes behind the foundation of UPF and the involvement of each agent in the organization.

Three episodes are chosen as subjects of analysis ${ }^{22}$ : the 2000-Assembly (Renewing the United Nations and Building a Culture of Peace), the organization process of the 2001-Assembly (Global Violence: Crisis and Hope) and its organization process, and the inauguration event of UPF in 2005. They are not in a cause-and-effect relationship, but certainly represent the pivotal concepts of the organization respectively. When they are juxtaposed with the historical context, such as the situation following 9/11, and the existing agents of the organization, they help us interpret the interfaith work of UPF and answer any questions regarding the transition from IIFWP to UPF.

21 According to the Marvasti, there are three kinds of interviews that are widely used. First is the structured interview, which sees interviewees as 'vessels of answers' and does not allow them to get away from the subject and the predetermined research categories to address it. Second, the unstructured interview allows interviewees to expand and advance their answers. The third sort of interview is a focus group interview which encourages a group of interviewees to interact and stimulate their answers. In this respect, I employed the unstructured interview method which contains an expanded personal narratives of research subjects. Amir B. Marvasti, Qualitative Research in Sociology (London: SAGE Publications, 2004), 14-34.

22 This is how I chose the episodes: first, with field meetings and readings of primary materials, I chose several potential time points that could be starting points to find the core episodes of the foundation phase of UPF. Second, by interviewing key members of UPF, I narrowed down the core episodes to three. 


\section{A Closer Look at the Foundation of Universal Peace Federation: The Three Episodes}

So far, we have seen the background and context of UPF. It is now clear that as an organization, which stems from the Unification Church, UPF is in continuity with the vision in development over four decades since the 1970s, and it is due to the doctrine of the movement that the legitimacy of interfaith enterprise was bolstered and supported. Its direct precursor, IIFWP, was started after the religious resurgence witnessed internationally during the 1990s. As the Unification Church and its leader started to promote the participation of religious bodies in the UN, the initiative of IIFWP focused on this agenda around the turn of the century. The active participation of the Unification Church in the UN, under the name IIFWP, was deemed to be successful enough to gain the Special Consultative Status with the ECOSOC. ${ }^{23}$ In 2005, the organization participating in the UN changed its name to UPF. UN paperwork shows that the former IIFWP and the new UPF has consisted of the same body, namely, the same staff and agenda. This relaunching into UPF is an important point that will be explained further below.

Another characteristic of UPF that we need to acknowledge is that it is a practically oriented organization. The interviews with the protagonists inside UPF suggest that the organization does not particularly emphasize the theoretical dimension of interfaith activity. For them, interfaith cooperation and coexistence is a basic fact of life, and without a doubt, a firm premise. Therefore, the focus here is what religions gathered under the interfaith flag can do for peacebuilding and resolving the problems that the world faces. I saw UPF centralizing the practical and actual effectiveness of religions in harmony. This is due to its prehistory of studying and researching the legitimacy and importance of interfaith dialogue. Dr. LaGroterria, the Director, Office of Operations, Finance, Legal Affairs, and Human Resources of UPF, mentioned that there has been enough debate on the interfaith dialogue per se. It is now time to embark on making an actual change in the world.

23 There are three kinds of consultative status: General consultative status, Special consultative status and Roster status. General status is assigned to "large international NGOs whose area of work cover most of the issues on the agenda of ECOSOC and its subsidiary bodies." However, Special status is given to "NGOs which have a special competence in, and are concerned specifically with, only a few of the fields of activity covered by the ECOSOC.” http://csonet.org/? menu=30 (accessed: 24.5.2020). For more detailed regulations, see ECOSOC Resolution 1996/31. 
I understand that the practical orientation led UPF to focus on participating in the UN, the effective and actual entity that is considered able to bring about a change. UPF has built a successful history of UN involvement. Mrs. ${ }^{24}$ Genie Kagawa, Director, Executive Office, emphasized that a few resolutions of the UN General Assembly actually made changes, and UPF made some contribution to the resolution along with allies in the UN. ${ }^{25}$

\subsection{Episode 1: The Foundation of the Precursor, IIFWP}

Let us first start with the name of the organization, IIFWP, as mentioned before, which is the acronym for "International and Inter-religious Federation for World Peace.” By juxtaposing "international” and "interreligious," this organization tries to bring together the secular and the sacred sphere ${ }^{26}$ : this agenda is speci-

24 I intentionally use "Mrs." here because Unification Church and its members put great value in (heterosexual) marriage due to its doctrine that emphasizes family. I observed that most married women members of the movement do not have qualms about the title "Mrs." indicating their marital status and the movement's official documents frequently use "Mrs."

25 Accordingly, the nation-states, which are based on secularism-especially the major Powers from the West that significantly influence the UN-will not be able to succeed in dealing with problems that our world faces today. This is the second pretext on participation of religious NGOs in the UN. The clear demarcation between the religious and the secular is the legacy of western Enlightenment period. This influenced the major participants of the UN, and until mid-90's, religion was not so much of a concern for this organization. The assembly of secularist states: this has been the basic premise of the UN. Nevertheless, the changing landscape of the global strife calls for the reconsideration of the very premise of secularism, and the cooperation of the religious and the secular. See Thomas Walsh, "Religion, Peace and the Post-Secular Sphere," International Journal on World Peace 29 (2012), 35-61. Dr. Walsh is the president of UPF and has been engaged in the interfaith movement for more than 30 years. He did his $\mathrm{PhD}$ in Vanderbilt University with a dissertation on the public sphere according to Jurgen Habermas. It can be said that Dr. Walsh's article represents very well the theoretical background of UPF and its activities. In terms of the perspective on the relation of religion and the UN, there has been a body of academic work. Lehmann summarized the academic works on this subject demarcating two currents of religious studies and socio-political studies. See Karsten Lehmann, "12.2: Religious Presence in the Context of the United Nations Organization" in Stanley Brunn ed., The Changing World Religion Map: Sacred Places, Identities, Practices and Politics vol. 4 (Dordrecht: Springer Netherlands, 2015).

26 The president of UPF, Dr. Thomas Walsh, has also argued for the overlapping of the secular and the religious spheres. His article on international politics and the role of religion after 9/11 highlights this line of argument. For the summary of the argument, see Thomas G. Walsh, "Religion, Peace and the Post-Secular Public Sphere," in International Journal on World Peace, Vol. 29, No. 2 (2012), 57-59. 
fied in the vision for the UN involvement, already discussed above. In this context, its launch needs to be understood in relation to the aforementioned Assembly 2000 (Renewing the United Nations and Building a Culture of Peace), one of the remarkable events convoked in the early period of the organization. In the proceeding of this 2000 assembly, the need for religious participation in the UN is buttressed in many ways as various experts in international relations, UN studies, NGO studies, etc. participated in the Assembly in 2000. ${ }^{27}$ According to the executive summary, the four major themes regarding renewal of the UN, which is under the major agenda on the cooperation of religious and political leaders for world peace, was discussed:

(1) The role of NGOs in the UN

(2) Conflict resolution and the role of religion and ideology

(3) The significance of family

(4) The concern for global environment. ${ }^{28}$

At this stage, the points (1) and (2) need particular attention since they represent the context of IIFWP and UPF. Religious NGOs, not nation-states that originally constitute the UN, are the point of interest in that they can offer solutions to the conflicts in the world.

Under auspices of these two causes, IIFWP was founded and has been actively engaged in international initiatives on the renewal of the UN. Starting from the ideal of the unity of cultures and various religions, the efforts for realizing the ideal were put into action in various ways since the mid- $20^{\text {th }}$ century. With the foundation of IIFWP, the action has been specifically aimed at implementing the religious council in the UN. IIFWP convened an international summit every year, contributed to UN resolutions and held countless events regarding issues on women and children in the late 90s and the year 2000. However, IIFWP soon went through a significant change on an organizational level: it was renamed as UPF in 2005.

Looking at the difference between the two sets of documents related to the foundation of IIFWP-unofficial and official-is helpful to understand the IIFWP's orientation and how this organization centralized its involvement with the UN. On the one hand, the 'unofficial', document internal to the organization has a strongly religious overtone. By 'religious', I mean that the members and actors in the organization are deeply embedded in a particular symbolic system

27 IIFWP, Renewing the United Nations and Building a Culture of Peace, 219-235.

28 IIFWP, Renewing the United Nations and Building a Culture of Peace, 219-235. 
and their motivations and activities are influenced by this system. ${ }^{29}$ On the other hand, the official and public version of the document shows a different tone.

First, there is a set of documents for people within the organization, containing the structure of the organization, personal mission statements, statement of purpose of the organization and the list of VIPs who could attend its conferences. $^{30}$ The date is not specified in the documents, but they are found in the year 2000 cabinet in the UPF office. Here, the relationship with other existing organizations within the Unification Church - such as WANGO and Ambassadors of Peace - and IIFWP is specified as above.

Although a total of 22 organizations are listed as associates of IIFWP, only four organizations are directly connected to the secretariat of IIFWP. It seems that in the Unification Church, there had been numerous organizations that dealt with the interreligious and peace-building agenda. Therefore, it was necessary for them to delineate the role and area of the new organization, IIFWP. Keeping into consideration the four main organizations that IIFWP relates to, helps us create a sense of what IIFWP aims for. These four organizations are: WANGO (World Association of Non-Governmental Organizations, Inc.), WCSF (World Culture and Sports estival), Ambassadors for Peace, and the World Peace Research Institution. ${ }^{31}$ Each stand for the area of NGO activity in the UN (WANGO), cultural and sporting events (WCSF), the network of international peace leaders (Ambassadors for Peace), and finally, the academic research on the subject.

However, the statements in the internal document are slightly different from the other two official and public statements in so far as they directly mention the religious theme in the Unification Church.

The IIFWP is not-for-profit educational corporation dedicated to sponsoring and organizing programs, seminars, publications and activities aimed at promoting respect, harmony, cooperation and peace among religions, nations, races, and culture around the world, and to cultivating a global network of individuals and associate organizations representing religion, politics, media professionals, scholars and educators, and representatives of civil society who work together in efforts to solve the critical problems which block the way to peace for individuals, families, societies, and nations.

29 This essay follows the Geertzian definition of religion as a working definition. See Clifford Geertz, "Religion as a Cultural System," in The Interpretation of Cultures: Selected Essays (Waukegan: Fontana Press, 1993), 87-125.

30 N.A, N.T., N.D.

31 On a Web site of Unification Church, the relationship between these organizations from the perspective of the church is described. http://www.tparents.org/Library/Unification/Pub lications/Smm-Org/works_world_peace.html (accessed: 24.5.2020). 
The IIFWP seeks to restore nations, by building on True Father's worldwide movement in every nation and the side range of organizations, each with a specific focus for the sake of establishing world peace. Internally IIFWP is guided by Divine Principle, Father's Words, and Unification Thought. The IIFWP Godism and a Heading Approach to solving problem..$^{32}$

The first paragraph does not particularly contain a religious element since it deals with the practical aims of the organization. However, the second paragraph explicitly shows the governing principle under the organization. Here, the "True Father" denotes the founder of the movement, Sun Myung Moon, and the script or the movement is mentioned. Moreover, directly mentioning the religious orientation is "internally" effective; this document clearly implies that its readers are the members of the organization.

However, those religious statements are diluted in public statements. Let us look at the other two official statements, which appeared around the foundation of the organization.

The Interreligious and International Federation for World Peace (IIFWP) is dedicated to the promotion of world peace through education programs, workshops, conferences, and publications. The IIFWP seeks to encourage and support the efforts of world leaders from all disciplines and the build coalitions among a wide range of non-governmental, religious, cultural, and educational institutions in advancing solutions to pressing world problems.

Of particular concern to the IIFWP are two serious and growing problems. The first revolves around family instability and breakdown and the serious social, economic, and cultural problems that family decline generates. The second concerns ethic, racial, and religious conflict in many parts of the world. There is a critical need for political, religious, and educational institutions to work together, not only to reverse the decline of the family, but also to promote greater understanding and collaborate among diverse communities. ${ }^{33}$

The first paragraph has similar phrases and structure than those found in the internal document. However, the second paragraph is completely different. It emphasizes the importance of family and the need for cooperation in every realm of our lives, such as the religious and political, to solve exigent problems that humanity faces. ${ }^{34}$ The second paragraph appears to be subtly written to re-

32 N.A, N.T., N.D. The quote is from the office document found in the year 2000 cabinet, which is a part of the preparation document for the launching of IIFWP.

33 N.A., IIFWP official booklet, page 1, published in 2000.

34 The ensuing paragraphs are as follows: The IFWP supports the mission of the United Nations and actively collaborates with the United Nations and other international and regional organizations dedicated to the cause of achieving justice, world peace, and human prosperity. The IIFWP supports the involvement of religious communities and organizations worldwide in coop- 
flect the organization's religious ideal and the UN participation simultaneously. The doctrine of Unificationism spotlights the recovery of family values, which, according to the founder, has remained destroyed since the time of Adam and Eve; however, this doctrine is also presented as compatible with the secular values of family, that is, it does not look particularly "religious." This statement promotes the vision of the organization, evading the overtone of particular religious movement in listing the movement's core doctrine of family values and mentioning the reason why the organization stresses the interaction of different realms to solve conflicts and problems in the world.

The difference between the two documents is the result of realistic concerns and experiences in the field that require subtle treatment regarding, in particular, religious statements. There are always dangers in mentioning religious values and doctrines in the field generally deemed to be 'secular'. Nevertheless, there are underlying religious motivations and convictions that played a role here, and this can be observed through the difference between the internal and public statements of the purpose of the organization. The first episode and materials produced in this context show us how IIFWP endeavored to balance religious motivations and realistic concerns in the field of IRD in the UN. Though interreligious dialogue is performed under the name of international cooperation and other humanitarian agendas, it is conducted by agents who are highly motivated by religious ideals.

Taking this into consideration, let us move to the second episode, which shows more specifically the engagement of the people in the organization.

\subsection{Episode 2: Immediate Action after 9/11, and the Muslim Network}

This section is still concerned with IIFWP, not UPF. To investigate the foundation of UPF, there is another set of episodes that need our attention. It represents the network and the investment in the human resources that the organization holds. One of these is our second episode, focused on the vitalization of religious debate in international politics. 9/11 shocked the entire world. What Samuel Huntington had argued seemed to be realized as a conflict between religions and cultures, not ideologies appeared to ensue. The Christian West and the Muslim

erative efforts for global peace. The IIFWP holds, furthermore, that international efforts for world peace on the part of the United Nations and other non-governmental organizations need to be enhanced by the unique e wisdom and insight of the world's great religious traditions. 
world were deemed to be opposing sides and the conflict became more palpable than ever. Right after the 9/11-events, IIFWP convened two events directly related to it - one in New York (in October) and the other in Jakarta (in December). People in the organization recollected the experience on two levels: the charisma of the founder that propelled the events; and the network with the Muslim world which IIFWP was able to make use of.

Conference proceedings and records are also helpful for understanding the two levels. First of all, the Assembly 2001 was held from 19 to 22 October in New York. It was right after the tragic attack in the very same city, and the staff recalled that nobody actually wanted to fly to New York. Conscious of the matter but not explicitly mentioning it, the Chairman's welcome remark in the official brochure is as follows:

As the twenty-first century began, at a time when the Cold War had ended, there was great hope that humanity might see a new millennium of greater peace, prosperity and happiness. However, recent events reveal the existence of many unresolved and unrestored problems, indicating that in this new century we face challenges as serious as in the past. We have gathered here to address these challenges. ${ }^{35}$

Mentioning the end of the Cold War as a background, and implying the current 9/11-event, the remarks open up the problems to be solved: it is the sphere of religion and culture that needs to be dealt with when we try to resolve an international crisis.

According to the online archive of UPF, this Assembly was successfully convened with 427 participants from all around the world. ${ }^{36}$ The agenda and initiatives of the Assembly were not so different from the previous year, the renewal of UN involvement, but focused more on the practical solution for violence under the name of religion. 12 conference reports from the event can be found on the Web archive of UPF and they try to sketch the general atmosphere of the conference. Unlike the reserved tone of the official welcome remarks, the reports present somewhat intense and strong emotional statements of the participants. For example, Rev. Moon invited 21 religious leaders ${ }^{37}$ to a private luncheon and

35 N.A., IIFWP Assembly 2001, Global Violence Crisis and Hope, official booklet page 2.

36 N.A., UPF Online data center: Conference List, page 2. Intranet material, not eligible for an external internet access.

37 Minister Louis Farrakhan (Nation of Islam), and his son, Mrs. Mohini Giri (Guild of Service, India), Chief Rabbi Izhak Bar-Dea and wife (Ramat-Gan, Israel), Dr. Manjit Singh Jathedar (Anand Pur Sahib, India), Reverend Junsei Terasawa (Nipponjan Myohoft, Russia and Ukraine), Chief Reuben Silverbird (Nedni Apache, Cherokee, Navajo), Father Nithya Sagayam (Bishops Council, India), Imam Muhammad Maqsood Ahmad Qadri (Dept. of Religious Affairs, Punjab, 
shared his opinions. In this luncheon, the reporter, Nadine Andre, recounts the exchange between Moon and the Honorable Minister (Louis Farrakhan Sr., 1933 - ) the leader of an American Islamic movement called the Nation of Islam. Before the conversation started, Moon gave the speech on "loving the enemy," in the aim of asserting that there should not be any concept of "enemy":

[There was then a brief, almost personal exchange between Dr. Moon and the Honorable Minister Farrakhan]

[The Minister responded]

But look at how you are speaking to us. You are passionate, not angry. That is how I speak. I am passionate too!

[Dr. Moon, smiling said]

Yes, but I am speaking of something different. I mean we should never point our finger to other groups. The highest way is to take responsibility; that is the only way.

[Then again to everyone present]

Pray to God to see if I am telling you the truth. If I am lying, come and destroy me. If you cannot get an answer easily, then do what I say, and see if that helps you find out. If I am wrong, come to me and we will repent together.

We do not need religious wars and denominationalism. Without denominationalism we must go to God.

If you don't believe what I'm saying, go to the spirit world; you will see I am telling the truth. $^{38}$

By reading this report, we can recognize that there had been personal exchanges among the religious leaders just a month after the 9/11 in the same city. In the other report, a heated debate is also documented. After Dr. Khalid Durán, a Muslim scholar who was recently expelled from the New Jersey Muslim association because of his academic work endorsing the expansion of the War in Afghanistan and condemning the contemporary situation in Sudan. Consequently:

This precipitated an outburst from several in the audience and an intervention from the session chair, who offered his profound apologies and stated that neither he nor the conference organizers were cognizant of the truth or falsehood of Dr. Duran's claims. On resum-

Pakistan), Dr. Allama Muhammad Idara Minhaj-Ul-Hussain Akbar (Idara Minhaj-Ul-Hussein, Pakistan), Chief Rabbi David Brodman (Savion, Israel).

38 Nadine Andre, Loving Your Enemy In The Face Of Terror: 21 Leaders of the World's Religions Meet United States: http://hoondok.ru/tfs/eng/2001/loving-your-enemy-in-the-face-of-terrortwenty-one-leaders-of-the-worlds-religions-meet (accessed: 24.5.2020). 
ing, Dr. Duran said the real problem was terrorist infiltration to the U.S. and the misuse of Islamic terminology and symbols. He said that the American Muslim majority would "not be a silent majority any longer" and would no longer be intimidated by the terrorist element. ${ }^{39}$

This part shows that the conference included a spectrum of Muslim participants and that they were deeply conscious of the situation they faced. In this respect, the conference was an intense experience for the participants at that time. However, the Unification Church propelled further effort to foster dialogue with the Muslim world, convening another conference.

Mr. Haj Hamad, the Secretary General of UPF, recollects that the founder wanted immediate action and called for the comprehensive gathering of Muslim leaders. It was not easy work, but fortunately, IIFWP was equipped with the staff that had already built a global network in the field. Dr. Hamad was one of them and he has been forming friendships with members of the NGO community. In 1998, he was even elected to a two-year term as Secretary of the NGO/DPI Executive Committee, the official umbrella group of NGOs in association with the UN Department of Public Information..$^{40}$ Additionally, he had a personal friendship with the former president of Indonesia, Abdurrahman Wahid and other important figures. The Jakarta Summit of Muslim leaders, which was held from 20 to 23 December 2001, was realized with the existing relationship and organization's network. According to Dr. Hamad, it was "a phone call" that initiated the summit, and Rev. Moon offered to fund every expense of the summit. ${ }^{41}$

39 Michael Mickler, Global Violence, Crisis and Hope: New Demands for Interfaith: Religions Must Take Greater Responsibility: https://www.tparents.org/UNews/Unws0111/IIrfwp_report. htm (accessed: 24.5.2020).

40 Harold Paine and Birgit Gratzer, Rev. Moon and the United Nations: https://www.global policy.org/component/content/article/176/31366.html (accessed: 24.5.2020). Also it is necessary to note that this report is written in highly derogatory tone to accuse Unification Church's participation in the UN in the respect of secularism, blaming the movement for "illegally" occupying the part of the UN. Nevertheless, it is one of the most detailed description on the activity of Unification Church in the UN.

41 Interview with Mr. Hamad, July 2014: "Also, the remarks of Dr. Walsh also help us understand the movement has built close relationship with a part of Muslim leaders in the world. In terms of Islam, I mentioned that one of the key points is this the grand mufti of Syria, Ahmed Koutaro, who I write about it in one article you have. And he formed a close relationship with Father Moon. And they had a strong mutual appreciation and respect. Because Koutaro was also a visionary. And at that time you know, Father Moon really emphasized the relationship and in 1990, at the Assembly, Father Moon said send me a group of fifties of your best leaders from Syria, in Islam. And bring them to New York, we will put them up in our hotel, the New Yorker Hotel, and that was something that Mr. Hamad can tell you about since he organized the pro- 
The ensuing summit following 9/11 and the passionate participation of Muslim agents show us the international conflicts come to appear in religious forms, not in ideological forms. Talking about religion in the public sphere - the UN and international politics- had been a taboo under the principle of the secularism. However, after 9/11 and its rupture, discussions on religion in the public sphere became inevitable.

\subsection{Episode 3: The (Re)birth of UPF and its Symbolic Meaning}

The last episode, the renaming of IIFWP to UPF can now be interpreted as an attempt to re-ignite the ideal for an interreligious council in the UN. Indeed, Rev. Moon founded UPF and specified the concept of the "Abel-type" and the "Cain-type" UN. The trope of Cain and Abel is from the biblical reference: the Cain-type UN refers to the existing secular UN system, which acts "selfishly and independently of God" while the "Abel-type" UN is said to have "an attitude of service to God and living for the sake of others." 42 Hence, UPF was not a sudden and new idea for a completely new vision. It is in continuity with the vision that had been developing over four decades, from the start of the movement. It seems that this was an invented rupture to advance its existing vision for UN engagement in a more compelling way. The staff, structure and the way they performed tasks remained the same. Only the name changed. This is thus a symbolic rebirth of the same agenda.

Mr. Hamad's personal network was an essential factor in the organization's capacity to carry out its mission. Considering the background and vitalization of religious voices in international politics and the UN, one can say that the involvement of IIFWP in the UN had been successful. Between 2001 and 2005, the organization held many activities as an NGO in the UN, by exerting efforts with allies in the UN to deliver the resolutions promoting and securing the status of religious NGOs. There are several important resolutions that promote the partic-

gram, they called the Interreligious Leadership Seminar. It was just a name, but they were primarily for Muslim leaders from Syria initially, then from Jordan, Egypt, from Yemen, 5 or 6 Muslim countries. And to build this relationship with Islam, also try to encourage this broader vision that both Rev. Moon and mufti Koutaro shared. So, way I interpret that is a form of preventive peace building."

42 Michael Mickler, “Toward an UN?: The Unification Movement and the United Nations,” Journal of Unification Studies 9 (2008). 
ipation of NGOs and interreligious activity..$^{43}$ Among them, the resolution adopted by the General Assembly on 19 December 2003 is important. It requested the UN Secretary General to disseminate the contents of the resolution, which welcomes the NGO's role and effort in interreligious dialogue. ${ }^{44}$ The term "request" designates a little stronger responsibility to the Secretary General than other resolutions.

Despite the vital and enthusiastic activities of IIFWP, the organization went through the renaming process from IIFWP to UPF. This move was an onerous job for an organization that already has a vast array of networks and a legal registration. They had to go through much paperwork to change the name into UPF. It seems that the motivation of this challenging transition is the need for further advancing the "Abel-type" UN vision. In this vein, the people in the organization referred primarily to the vision of the "Abel UN" as a core concept of the new UPF. Around 2005, Rev. Moon started to introduce this concept, which is the opposite concept of the "Cain UN," indicating that the secularized UN structure that cannot effectively deal with the current problems in the world, requiring regular participation of religious bodies. The structure of his argument is similar to the 2000 UN renewal Assembly, which initiated IIFWP.

All the conflicts and wars in history have been essentially battles between a Cain camp, relatively tending towards evil, and an Abel camp, relatively tending toward goodness. Humanity must end these struggles between Cain and Abel camps and restore the original state of harmony and love. To do this, each of us must end the conflict between our mind and body, and bring them into harmonious union. [...]

The existing United Nations structure, composed of national representatives, may be regarded as a congress where the interests of each member nation are represented. However, I submit that serious consideration should be given to forming a religious assembly, or council of religious representatives within the structure of the United Nations. This assembly or council would consist of respected spiritual leaders in fields such as religion, culture, and education. Of course, the members of this interreligious assembly will need to have

43 To list them: Promotion of Interreligious and Intercultural Dialogue, Understanding, and Cooperation for Peace, GA 60/10, adopted 3 November 2005; Promotion of Interreligious Dialogue, GA 59/23, adopted 11 November 2004; Promotion of Religious and Cultural Understanding, Harmony, and Cooperation, GA 58/128, adopted 19 December 2003.Moreover, at the center of the realization of these resolution and the cooperation of IIFWP and other NGO, one should not omit to mention Mrs. Kagawa facilitation during the whole process in the UN.

44 UN General Assembly, Resolution: Promotion of Religious and Cultural Understanding, Harmony and Cooperation: A/RES/58/128. 
demonstrated an ability to transcend the limited interests of individual nations and to speak for the concerns of the entire world and humanity at large. ${ }^{45}$

Here, the trope of Abel and Cain is used, as well. However, the trope has not advanced to the concept of the "Abel-type" UN. In 2000, Moon only argues that an interreligious council is essential in the UN, since the conflicts in the world after the Cold War called for the reconsideration and recognition of religious powers. This logical sequence is not so much different in 2005.

The United Nations has made important contributions for peace. Nevertheless, at its 60th anniversary there is a broad consensus, both inside and outside the organization, which the U.N. has yet to discover the way to fulfill its founding purposes. The number of member states is approaching 200, but the offices of these states do little more than represent and even insist on their own interests. They seem inherently unable to resolve conflicts and achieve peace.

For these reasons, I declare today before all humanity the founding of a new international organization, the Universal Peace Federation. Its mission is to renew the existing United Nations and provide a new level of leadership as an "Abel-type" United Nations, that is, a United Nations whose efforts for peace are offered to Heaven, investing itself ceaselessly in living for the sake of others. ${ }^{46}$

Finally, this section analyzes the inaugural conference of UPF in 2005 Seoul, along with the interview with Dr. Frank LaGrotteria who delivered the practical and logistical dimension of the conferences and summits that UPF often held. He described how he was impressed by the grandiose nature of the inaugural events carried with ritualistic ceremonies and showed me various media clips recorded at the event: the sound of a huge Chinese gong, the prayers, and the atmosphere of the ceremony was different from previous ones. Moreover, the founder started to travel to 120 nations in the world to commemorate and promote the UPF launch and Dr. LaGrotteria recalled that it had symbolic importance for the members of the organization..$^{47}$

In sum, it appears that this re-launching of the same body with a different name has a symbolic meaning for the members of the organization. Finally, the fact that around 2005, at the transitional moment of the IIFWP to UPF, the two names appear simultaneously on the brochures and posters of events the or-

45 N.A. "S.M. Moon Address: Renewing the United Nations to Build Lasting Peace, August 2000.

46 N.A. "S.M. Moon Address".

47 From my personal exchange with Dr. LaGrotteria. in UPF headquarter on July $8^{\text {th }} 2014$. 
ganization held gives us strong confirmation that the foundation of UPF is in deep continuity with the IIFWP. ${ }^{48}$

What this rebirth means can be interpreted in many ways. However, considering the IIFWP's previous work and the religious turn following 9/11, the renaming seems to aim at advancing the religious agenda and propelling the organization's religious ideal within the context of its UN participation. As religious entities and agents begin to be granted admission in the realm of international relations and politics in early 2000, UPF attempts to reignite its activity by relaunching the organization. Moreover, what promoted the rebirth of UPF is the fact that the IRD movement became an agenda that draws attention from major entities of international politics and thus, expanded its influence in the public sphere in general. The two previous episodes mark the starting point of this trend and UPF's launch shows us continuing efficacy of the religious agents and values in the public sphere, especially that of the U.N. The 9/11-events were a watershed moment that led to the convergence of religious and secular dynamics within international politics. It opened up a new stream of IRD. IIFWP and UPF are at the heart of this trend, and their foundation and activity give us an emblematic example of IRD in the public sphere, especially in the realm of international relations and cooperation.

\section{Conclusion}

A significant advance in the UN resolution was brought about under the name of UPF. A resolution, which was adopted by the General Assembly on 20 December 2006, directly requests the Secretary General to include interreligious matters:

16. Requests the Secretary-General to ensure the systematic and organizational follow-up of all interreligious, intercultural and inter-civilizational matters within the United Nations system and overall coordination and coherence in its interreligious, intercultural and inter-civilizational dialogue and cooperation efforts, inter alia, through the designation of a focal unit in the Secretariat to handle these matters. ${ }^{49}$

Mrs. Kagawa, who is in charge within UPF of UN relations and resolutions, said that this request "ensuring" supporting interreligious with the "focal unit" ac-

48 International Interreligious Federation for World Peace, ed. The World Leadership Convocation. N.P. 2005. Universal Peace Federation, ed. The World Assembly. N.P. 2006.

49 UN General Assembly, Resolution: Promotion of Interreligious and Intercultural Dialogue, Understanding and Cooperation for Peace : A/RES/61/221.http://digitallibrary.un.org/record/589511/ files/A_RES_61_221-AR.pdf (accessed 23.10.2020) 
tually calls for the institutional support for the interfaith NGOs in the UN. This is considered to be a decisive step forward in the field.

As we have seen above, UPF is an active and living organization in the field of international NGOs that specializes in interfaith dialogue and conflict resolution. The important thing is that not only the fact that the three episodes took place, but also the fact that people in the organization affirmed that these episodes are important and meaningful to them. This approach, which focuses on the accounts of the participants, is crucial for understanding interfaith activity as a religious phenomenon. This is a dimension that can be observed at a microscopic level, focusing on the activity of individual agents in the organization.

In addition, we can analyze the background and effective activity of UPF in terms of shifting landscape of the religious and the secular. To be specific, the success of UPF is largely in accordance with the contemporary adaptation of religious organizations integrating into or appropriating the realm of the secular such as the UN. As Lehmann earlier observed in the cases of the Commission of the Churches on International Affairs, Pax Romana, and the Friends World Committee for Consultation, ${ }^{50}$ Religious NGO's participation in the secular realm, such as the UN, implies the contested distinction between the religious and the secular, and thus shows new possibilities for religious NGOs. These organizations respectively pursue their religious goals by way of engaging in NGO activities, taking part in secular institutions such as the UN.

UPF can be considered a case of the above tendency. By investigating the foundation background of the UPF, this analysis made connections between ideas of religious actors, historical context and the contemporary interreligious dialogue movement within particular developments in international relations, especially within the United Nations. Now it is clear that UPF effectively attended to its agenda, showing a compelling possibility and example of interfaith dialogue in the contemporary world by adapting to the structure of secular organizations, i.e. the UN. UPF, after its major 2000 conference and the two that immediately followed 9/11 in 2001 shows regular participation in the UN and in the realm of international politics. The case of UPF strongly underlies the fact that the status of the IRD movement has been elevated to the level of general international politics and cooperation. Listing and arguing the legitimacy of IRD is not the only aim of the IRD movement anymore. Interreligious dialogue is now an indispensable part of human lives and a simple fact of life in the post-globalization era. Taking actions at an international level in specific agendas - pro-

50 Karsten Lehmann, "Shifting Boundaries Between the Religious and the Secular: Religious Organizations in Global Public Space," Journal of Religion in Europe 6 (2013): 1-28. 
moting rights of women and youth, and international peace-building, etc. - became major concerns of the IRD movement. The increasing importance of the religious sphere after $9 / 11$ and this change in the setting of the IRD movement was the catalyst for the foundation, or, the symbolic rebirth of UPF. Thus, UPF shows us compelling evidence of this trend, namely, the collapsing of the wall between secular and religious discourse in the public sphere as reflected in particular in the UN international public space.

\section{Bibliography}

\subsection{Primary Sources}

Mickler, Michael, “Global Violence: Crisis And Hope: New Demands For Interfaith: Religions Must Take Greater Responsibility," UPF Conferences: Assembly 2001, Global Violence: Crisis and Hope, October 19, 2001. http://www.upf.org/resources/downloads (accessed: 24.5.2020).

Paine, Harold and Birgit Gratzer. Rev. Moon and the United Nations: November 2001. https:// www.globalpolicy.org/component/content/article/176/31366.html (accessed: 24.5. 2020).

IIFWP. Renewing the United Nations and Building a Culture of Peace: A Report from the Interreligious and International Federation for World Peace Assembly 2000. New York: IIFWP, 2000.

IIFWP, ed. The World Leadership Convocation. N.P. 2005.

N.A. "S.M. Moon Address: Renewing the United Nations to Build Lasting Peace", August 2000.

N.A., IIFWP Assembly 2001, Global Violence Crisis and Hope, official booklet page 2.

N.A., IIFWP official booklet, page 1. Published in 2000.

N.A., UPF Online data center: Conference List, page 2. Intranet material, not eligible for an external internet access.

Nadine, Andre. Loving Your Enemy In The Face Of Terror: 21 Leaders of the World's Religions Meet United States: http://www.upf.org/resources (accessed: 24.5.2020).

Promotion of Interreligious and Intercultural Dialogue, Understanding, and Cooperation for Peace, GA 60/10, adopted 3 November 2005.

Promotion of Interreligious Dialogue, GA 59/23, adopted 11 November 2004.

Promotion of Religious and Cultural Understanding, Harmony, and Cooperation, GA 58/128, adopted 19 December 2003.

Universal Peace Federation, ed. The World Assembly. N.P. 2006.

UN General Assembly, Resolution: Promotion of Religious and Cultural Understanding, Harmony and Cooperation: A/RES/58/128. 


\subsection{Secondary Sources}

Barker, Eileen. “Unification Church.” In Encyclopedia of Global Religion, edited by Mark Juergensmeyer and Wade Clark Roof. Thousand Oaks: Sage Publications, 2012.

Braybrooke, Marcus. Pilgrimage of Hope. Philadelphia: Trinity Press International, 1991. Bromley, David G. and Anson D. Shupe, Jr. “Moonies” in America. Thousand Oaks: Sage Publication, 1979.

Chryssides, George D. The Advent of Sun Myung Moon. New York: St. Martin's Press, 1991.

Coffey, Amanda. "Analyzing Documents." In The SAGE Handbook of Qualitative Data Analysis, ed. Uwe Flick. London: SAGE Publications, 2014.

Geertz, Clifford. "Religion as a Cultural System." In: The Interpretation of Cultures: Selected Essays, 87-125. Waukegan: Fontana Press, 1993.

Hutchinson, Dawn. Antiquity and Social Reform. Newcastle: Cambridge Scholars Publishing, 2010.

Lehmann, Karsten. "12.2: Religious Presence in the Context of the United Nations Organization" In The Changing World Religion Map: Sacred Places, Identities, Practices and Politics, vol. 4, edited by Stanley Brunn. Dordrecht: Springer Netherlands, 2015.

Lehmann, Karsten. "Shifting Boundaries Between the Religious and the Secular: Religious Organizations in Global Public Space.” Journal of Religion in Europe 6 (2013): 1-28.

Marvasti, Amir B. “Interviews.” In Qualitative Research in Sociology. London: SAGE Publications, 2004.

Mickler, Michael. "Toward an "Abel" UN? The Unification Movement and the United Nations." Journal of Unification Studies 9 (2008).

Sontag, Frederick. Sun Myung Moon and Unification Church. Nashville: Abingdon, 1977.

Stark, Rodney and John Lofland. "Becoming a World-Saver: A Theory of Conversion to a Deviant Perspective.” American Sociological Review 30/6 (1965): 862-875.

Walsh, Thomas. "Religion, Peace and the Post-Secular Sphere." International Journal on World Peace 29/2 (2012): 35-61. 